\title{
The Effect of Financial Variables on Systematic Risk in Six Industries in Thailand
}

\author{
Vilayphone Vongphachanh*, Khairunisah Ibrahim
}

Faculty of Economics and Management Sciences, International Islamic University Malaysia, MALAYSIA

*Corresponding Contact:

Email: vilayphone1512744@gmail.com

Manuscript Received: 15 July 2020 - Revised: 29 August $2020 \quad$ - Accepted: 17 Sept 2020

\begin{abstract}
Risk is classified into two types which are systematic risk and unsystematic risk. Unsystematic risk is known as a diversifiable risk that can be avoided or managed. On the other hand, systematic risk is the market-related risk which cannot be controlled or diversified away. Between these two types of risks, the systematic risk becomes the major concern of firms and investors as this type of risk cannot be avoided or diversified away, but need to be strategized and managed accordingly. The purpose of this study is to examine the main factors influence on the behavior of systematic risk in six industries of Thailand, the period of study is 15 years from 2002 to 2016 and consist of 372 non-financial listed firms. This study employs the panel data analysis, comprising of the random effect model (REM), fixed effect model (FEM), and pool ordinary least square (POLS). The overall findings show some common financial variables such as financial leverage, liquidity, firm size, firm growth, and profitability are considered as the main factors affecting systematic risk in Thai consumer goods, technology, telecommunication, utilities, and health care. However, Thai consumer service is reported as an insignificant relationship between financial variables and systematic risk. Apart from financial variables, there is an impact of the financial crisis (2009) on systematic risk in all industries. Findings in this study extent in the finance literature on systematic risk, different internal industries may have different factors influencing the behavior of systematic risk.
\end{abstract}

Keywords: systematic risk, profitability, growth, liquidity, financial leverage, operating efficiency

This article is is licensed under a Creative Commons Attribution-NonCommercial 4.0 International License.

Attribution-NonCommercial (CC BY-NC) license lets others remix, tweak, and build upon work non-commercially, and

although the new works must also acknowledge \& be non-commercial.

\section{INTRODUCTION}

Risk is known as uncertainty which involves any activity of investment. Normally, the risk is classified into two types which are unsystematic risk and systematic risk. Unsystematic risk is known as a specific risk to firms which can control and reduce through 
diversification, this type of risk caused by internal factors such as mismanagement and so on. Systematic risk is the market relates risk which cannot avoid and will affect the market as a whole, it is known as un-diversifiable risk (Markowitz, 1952).

According to the nature of systematic risk and unsystematic risk, the most concern for firms' managers and investors is a systematic risk since it cannot diversify away. Firms' managers and investors have played more attention in finding a way to understand and managed systematic risk in orders to prevent their investment from a lost (Gitman \& Zutter, 2012; Alaghi, 2012). In the finance literature stated that, the higher profit can be achieved by reducing the portion of the risk, that is, it is very important for firms' managers and investors to understand the nature of risk especially systematic risk since unsystematic risk can reduce through diversification. By understanding the nature of systematic risk may help firms' managers and investors can develop new strategies dealing with this type of risk (Iqbal \& Ali Shah, 2012).

This study examines the specific factor affecting systematic risk in six industries of Thailand by focusing on all non-financial listed firms within 15 years from 2002 to 2016. Additionally, this study also examines the effect of the global financial crisis (2009) on systematic risk. The findings of this study may provide new evidence and useful information to extend in the literature which may help to increase the current understanding of systematic risk. Understanding the source of systematic risk of different industries may assist firms to know how to handle systematic risk issue during the financial crisis and normal economic situation. This may result in an increase in firms' efficiency and profitability in the future.

\section{LITERATURE REVIEW}

According to the capital asset pricing model, systematic risk is very important as compare to unsystematic risk. That is because systematic risk plays an important role in determining the expected return of stocks, this type of risk is known as the external impact which cannot be avoided or reduced through diversification. Systematic risk indicates the risk of firms related to market risk, so if the systematic risk of firms is higher than market risk. This will affect to return of shareholders when there is a loss by the movement of the stock price, that is, the stock price can be changed depending on the change of systematic risk (Alaghi, 2013).

Previously, there are several studies attempted to find ways to understand the nature of the sources of systematic risk by using firm-specific variables such as firm size, liquidity, profitability, growth, operating efficiency and financial leverage to determine systematic risk in financial and non-financial firms of a particular market. The results of these studies have shown a relationship between systematic risk and firm-specific variables (see for example; Mandelker \& Rhee, 1984; Borde, 1998; Gu \& Kim, 2002; Hamada, 1972; Lee \& Jang, 2007; Aruna \& Warokka, 2013).

Iqbal and Ali Shah (2012) studied the effect of financial variables on systematic risk by focusing on non-financial firms listed in Karachi Stock Exchange within 4 years from 2005 to 2009. Their results show that firm size, profitability and growth are positively associated with systematic risk, but leverage liquidity, operating efficiency is negatively related to systematic risk. Similarly, Aruna and Warokka (2013) examined the specific factors affecting systematic risk in the manufacturing industry of Indonesia within 2 years from 
2005 to 2007. They found that only growth is positively associated with systematic risk while leverage, firm size and liquidity is negatively associated with systematic risk.

Alaghi (2013) investigated a relationship between firm-specific variables and systematic risk of non-financial firms in the Tehran Stock Exchange. Their finding showed that there is no any relationship between firm size and systematic risk, but liquidity, profitability, operating efficiency, and leverage have a significant impact on systematic risk. Furthermore, a study conducted by Lee and Jang (2007) focused on firm-specific factors determining systematic risk in the US airline industry. Their study has shown that there is no relationship between liquidity and systematic risk while firm size, safe, leverage, profitability and growth are related to systematic risk. However, even though previous studies found there is a relationship between systematic risk and firm-specific variables but previous studies only provided a mixed result or inconclusive result which cannot specify which are the main factor affecting systematic risk. Therefore, this may not provide sufficient information to make a sound decision for firms' managers and investors. Systematic risk is the market relates risk which cannot diversify away, it is the main factor affecting stocks' return. Thus, understanding the sources of systematic risk is very crucial for firms' manager and investors in order to develop new approaches dealing with this type of risk in the future.

\section{Methodology}

This study includes 372 non-financial listed firms which derived from six industries such as consumer goods, consumer service, telecommunication, utilities, health care and technology. Financial firms are excluded from this study due to a different capital source and rule. This study uses panel data approach such a fixed-effect model, random effect model, and pooled ordinary least squares to estimate the parameter of interests. There are three tests to select which is the best model such as Chow test, Hausman test, and Breusch and Pagan test. The regression for this study is shown below:

$Y_{i, t}=a_{0}+a_{1}$ Operating efficiency $_{i, t}+a_{2}$ Financial leverage $_{i, t}+a_{3}$ Firm growt $_{i, t}+$

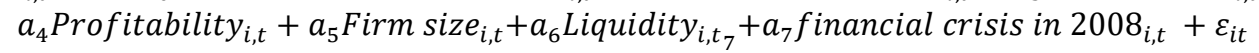

The development of hypothesis in this study base on previous studied which shown as below:

$\mathrm{H}_{1}$ : Operating efficiency is negatively related to systematic risk.

$\mathrm{H}_{2}$ : $\quad$ Financial leverage is positively related to systematic risk.

$\mathrm{H}_{3}$ : $\quad$ Firm Growth is positively related to systematic risk.

$\mathrm{H}_{4}$ : $\quad$ Profitability is negatively related to systematic risk.

$\mathrm{H}_{5}$ : $\quad$ Firm size is positively related to systematic risk

$\mathrm{H}_{6}$ : $\quad$ Liquidity is positively related to systematic risk.

$\mathrm{H}_{7}$ : $\quad$ Financial crisis in 2008 has a significant influence on systematic risk.

The most appropriate model for each industry of Thailand achieves by running three tests such as Chow test, Hausman test, and Breusch and Pagan test. Pooled ordinary least square is considered as the best estimator for all Thai industries in this study, a summary of findings is shown in Table 1 below. 
Table 1: Summary of the three test results for Thai industries

\begin{tabular}{|l|l|l|l|}
\hline Industries & \multicolumn{1}{|c|}{ Chow Test } & \multicolumn{1}{c|}{ Hausman Test } & \multicolumn{1}{c|}{ BP-LM test } \\
\hline $\begin{array}{l}\text { Consumer } \\
\text { goods }\end{array}$ & $\begin{array}{l}\text { Do not reject } H_{0} \\
\text { Pooled OLS better than FEM } \\
\text { F-state }=3.70\end{array}$ & $\begin{array}{l}\text { Do not Reject } H_{0} \\
\text { REM better than FEM } \\
\text { Chi2 }=9.46\end{array}$ & $\begin{array}{l}\text { Do not reject } H_{0} \\
\text { Pooled OLS better than REM } \\
\text { chibar2 }=0\end{array}$ \\
\hline $\begin{array}{l}\text { Consumer } \\
\text { Product }\end{array}$ & $\begin{array}{l}\text { Do not reject } H_{0} \\
\text { Pooled OLS better than FEM } \\
\text { F-state }=1.94\end{array}$ & $\begin{array}{l}\text { Do not Reject } H_{0} \\
\text { REM better than FEM } \\
\text { Chi2 }=2.66\end{array}$ & $\begin{array}{l}\text { Do not reject } H_{0} \\
\text { Pooled OLS better than REM } \\
\text { chibar2 }=0\end{array}$ \\
\hline Technology & $\begin{array}{l}\text { Do not reject } H_{0} \\
\text { Pooled OLS better than FEM } \\
\text { F-state }=2.02\end{array}$ & $\begin{array}{l}\text { Do not Reject } H_{0} \\
\text { REM better than FEM } \\
\text { Chi2 }=15.38\end{array}$ & $\begin{array}{l}\text { Do not reject } H_{0} \\
\text { Pooled OLS better than REM } \\
\text { chibar2 }=0\end{array}$ \\
\hline $\begin{array}{l}\text { Telecommu } \\
\text { nication }\end{array}$ & $\begin{array}{l}\text { Do not reject } H_{0} \\
\text { Pooled OLS better than FEM } \\
\text { F-state }=0.37\end{array}$ & $\begin{array}{l}\text { Do not Reject } H_{0} \\
\text { REM better than FEM } \\
\text { Chi2 }=2.30\end{array}$ & $\begin{array}{l}\text { Do not reject } H_{0} \\
\text { Pooled OLS better than REM } \\
\text { chibar2 }=0\end{array}$ \\
\hline Utilities & $\begin{array}{l}\text { Do not reject } H_{0} \\
\text { Pooled OLS better than FEM } \\
\text { F-state }=1.22\end{array}$ & $\begin{array}{l}\text { Do not Reject } H_{0} \\
\text { REM better than FEM } \\
\text { Chi2 }=8.68\end{array}$ & $\begin{array}{l}\text { Do not reject } H_{0} \\
\text { Pooled OLS better than REM } \\
\text { chibar2 }=0\end{array}$ \\
\hline Health care & $\begin{array}{l}\text { Do not reject } H_{0} \\
\text { Pooled OLS better than FEM } \\
\text { F-state }=0.49\end{array}$ & $\begin{array}{l}\text { Do not Reject } H_{0} \\
\text { REM better than FEM } \\
\text { Chi2 }=10.12\end{array}$ & $\begin{array}{l}\text { Do not reject } H_{0} \\
\text { Pooled OLS better than REM } \\
\text { chibar2 }=0\end{array}$ \\
\hline
\end{tabular}

\section{FINDINGS AND DISCUSSION}

According to a summary of full sample for six industries of Thailand in Table 2, it evidences that financial variables are not significantly related systematic risk in consumer service while other industries found at least one variable is associated such as Thai consumer goods shown financial leverage as the main factor, technology is profitability, telecommunication is liquidity, utilities are firm growth and firm size, and health care is firm growth. The less financial variables which did not mention as the main factor are insignificant related to systematic risk. Aruna and Warokka (2013) use some of the accounting variables such as leverage, liquidity, firm size and firm growth to determine systematic risk in Indonesian manufacturing, they found there is not any significant relationship between accounting variables and systematic risk. Therefore, it can be said that systematic risk can be explained by financial variables but not all of the financial variables can be used to influence the behaviour of systematic risk, it depends on the characteristic of industries as well. Besides financial variables, the global financial crisis (2009) is significantly correlated to systematic risk in all industries. This result is supported the seventh hypothesis (H7) of this study.

Table 2: Summary of full sample for six industries

\begin{tabular}{|c|c|c|c|c|c|c|}
\hline \multirow{2}{*}{ Hypothesis } & \multicolumn{7}{|c|}{ Thailand } \\
\cline { 2 - 7 } & $\begin{array}{c}\text { Consumer } \\
\text { good }\end{array}$ & $\begin{array}{c}\text { Consumer } \\
\text { service }\end{array}$ & Technology & $\begin{array}{c}\text { Telecom- } \\
\text { munition }\end{array}$ & Utilities & Healthcare \\
\hline H1 & No & No & No & No & No & No \\
\hline H2 & Yes & No & No & No & No & No \\
\hline H3 & No & No & No & No & Yes & Yes \\
\hline H4 & No & No & Yes & No & No & No \\
\hline H5 & No & No & No & No & Yes & No \\
\hline H6 & No & No & No & Yes & No & No \\
\hline H7 & yes & yes & Yes & Yes & Yes & Yes \\
\hline
\end{tabular}

Notice: "Yes" supported the hypothesis, "No" not supported the hypothesis. 


\section{CONCLUSION}

Previously, numerous studies have been done on examining the impact of firm-specific variables on systematic risk in local and international firms. However, these studies focused on particular industries such as the airline industry, restaurant industry, manufacturing, banking, tourism and so on. By focusing only on a particular industry, these studies have provided an inconclusive finding which cannot specify clearly which is the main factor affecting systematic risk. Therefore, previous studies may not provide sufficient information for firms to understand the nature of systematic risk issue or sources of systematic risk and have a sound decision on their business. This study examines the relationship between financial variables and systematic risk in non-financial listed firms across various industries in Thailand within 15 years from 2002 to 2016. This study may help firms' managers and investors to enhance their understanding of the nature of the systematic risk or an impact of financial leverage, firm size, growth, operating efficiency and profitability on systematic risk. By understanding the sources of systematic risk in non-financial firms across various industries in Thailand may assist firms' managers and investors to have a good strategy dealing with systematic risk issue in the future which may lead to increase in the profitability and efficiency of the firms. Moreover, this study also examines the impact of the global financial crisis in 2009 on systematic risk. Therefore, understanding the sources of systematic risk issue which relates to the financial crisis in 2008 may help firms' managers and investors to be able to generate a healthy plan dealing with risk.

\section{REFERENCES}

Alaghi, K. (2012). Operating leverage and systematic risk. African Journal of Business Management, 6(3), 1095-1099. https://doi.org/10.5897/AJBM11.2266

Alaghi, K. (2013). Determinants of Systematic Risk of the Listed Companies in Tehran Stock Exchange. Journal of Basic and Applied Scientific Research, 3(1), 596-600.

Aruna, D. C., \& Warokka, A. (2013). Systematic risk and accounting determinants: a new perspective from an emerging market. J. for Global Business Advancement, 6(1), 24. https://doi.org/10.1504/JGBA.2013.053476

Borde, S. F. (1998). Risk diversity across restaurants: An empirical analysis. Cornell Hotel and Restaurant Administration Quarterly, 39(2), 64-69. https://doi.org/10.1016/S0010-8804(98)80013-X

Gitman, L. J., \& Zutter, C. J. (2012). Principles of Managerial Finance (13th ed.). Pearson Education Limited.

Gu, Z., \& Kim, H. (2002). Determinants of Restaurant Systematic Risk: A Reexamination. The Journal of Hospitality Financial Management, 10(1), 1-13. https:/ / doi.org/10.1080/10913211.2002.10653757

Hamada, R. S. (1972). The Effect of the Firm's Capital Structure on the Systematic Risk of Common Stocks. The Journal of Finance, 27(2), 435-452. https://doi.org/10.1111/j.1540-6261.1972.tb00971.x

Iqbal, M. J., \& Ali Shah, S. Z. (2012). Determinants of Systematic Risk. The Journal of Commerce, 4(1), 47-56. https://doi.org/10.2307/2329688

Lee, J. S., \& Jang, S. C. (Shawn). (2007). The systematic-risk determinants of the US airline industry. Tourism Management, 28(2), 434-442. https://doi.org/10.1016/j.tourman.2006.03.012

Mandelker, G. N., \& Rhee, S. G. (1984). The Impact of the Degrees of Operating and Financial Leverage on Systematic Risk of Common Stock. Journal of Financial and Quantitative Analysis, 19(1), 45-57. https://doi.org/10.2307/2331000

Markowitz, H. (1952). Portfolio Selection. The Journal of Finance, 7(1), 77-91. https://doi.org/10.1111/j.1540-6261.1952.tb01525.x

$$
--0--
$$




\section{How to cite this article}

Vongphachanh, V., \& Ibrahim, K. (2020). The Effect of Financial Variables on Systematic Risk in Six Industries in Thailand. ABC Journal of Advanced Research, 9(2), 63-68. https://doi.org/10.18034/abcjar.v9i2.512 